\title{
The effects of salicylic acid, oxalic acid and chitosan on damping-off control and growth in Scots pine in a forest nursery
}

\author{
Anna Soltys ${ }^{(1)}$, \\ Marcin Studnicki ${ }^{(2)}$, \\ Grzegorz Zawadzki ${ }^{(1)}$, \\ Marta Aleksandrowicz-Trzcińska(1)
}

\begin{abstract}
Modern forestry in the European Union and in Poland is in constant search of environment-friendly technological solutions. These also relate to nursery production, in which attempts are made to apply non-chemical plant-protection products. The objective of this study was to assess the effects of salicylic acid, oxalic acid and chitosan (applied in the form of Beta-chikol ${ }^{\oplus}$ ) in controlling damping-off and promoting the growth of Scots pine seedlings under nursery conditions. All the substances were used in seed treatment and in the form of foliar spray, 4 times during the growing season, in the following concentrations: salicylic acid $1 \%$ and $2 \%$, oxalic acid $0.5 \%$ and $1 \%$, and chitosan $2 \%$. Seedlings were inventoried three times: 3 and 6 weeks after seed sowing, and at the end of the growing season. All seedlings were counted in 1-metre segments of individual rows of the seedbed. At the end of the growing season, parameters of seedling growth like shoot length, root-collar diameter, root length and the dry mass of above-ground parts were determined. The growth of pine seedlings was found to be stimulated by both chitosan and oxalic acid, while salicylic acid proved inhibitory to growth when present at $2 \%$ concentration, and showed no detectable influence on biometric parameters at $1 \%$ concentration. Numbers of seedlings germinating per 1-metre segment were significantly greater than in the (unprotected) control, where chitosan was applied. Likewise, oxalic acid applied at both concentrations was associated with greater numbers of germinating pine seedlings than in the control, albeit the statistical significance of this difference was achieved only 6 weeks after seed sowing, and only with the $0.5 \%$ concentration. Numbers of seedlings per metre-long segment were significantly lower in response to both concentrations of salicylic acid applied. Both chitosan (applied as Beta-chikol ${ }^{\circ}$ ) and $0.5 \%$ oxalic acid resulted in seedling protection against damping-off and enhanced growth, whereas the applied concentrations of salicylic acid were presumably excessive, hence the negative impact on both germination and growth.
\end{abstract}

Keywords: Plant Biostimulants, Induced Resistance, Pinus sylvestris, Growth Stimulation, Disease Control

\section{Introduction}

Damping-off of seedlings is a fungal disease capable of generating major losses in forest nurseries. It is caused by pathogens belonging to a range of different systematic groups, including genera Rhizoctonia, Fusarium, Cylindrocarpon, and Phytophthora (Enebak et al. 1990, Beyer-Ericson et al. 1991). This heterogeneity of origin combines with the emergence of resistance to

fungicides to make this disease very hard to combat (Goffeau 2008).

Modern forestry in the European Union and in Poland is in constant search of environment-friendly technological solutions. This is also true for nursery production, in which alternatives to agrochemicals are being looked for. Induced resistance has emerged as a potential alternative or complementary strategy for the control of

$\square$ (1) Department of Forest Protection, Institute of Forest Sciences, Warsaw University of Life Sciences, Nowoursynowska 159, 02-776 Warsaw (Poland); (2) Department of Biometry, Institute of Agriculture, Warsaw University of Life Sciences, Nowoursynowska 159, 02-776 Warsaw (Poland)

@ Marta Aleksandrowicz-Trzcińska (marta_aleksandrowicz_trzcinska@sggw.pl)

Received: Sep 20, 2019 - Accepted: Jul 24, 2020

Citation: Soltys A, Studnicki M, Zawadzki G, Aleksandrowicz-Trzcinska M (2020). The effects of salicylic acid, oxalic acid and chitosan on damping-off control and growth in Scots pine in a forest nursery. iForest 13: 441-446. - doi: 10.3832/ifor3244-013 [online 2020-09-24]

Communicated by: Alberto Santini plant diseases (Jayaraj et al. 2010, MartínGarcía et al. 2019).

Chitosan $(\mathrm{CH})$ is a naturally-occurring polysaccharide which is a deacetylated derivative of chitin. It serves as an exogenous elicitor of plant defence responses. It induces local and systemic acquired resistance, as reflected in the activation of reactive oxygen species, synthesis of salicylic acid, phytoalexins, polyphenolics, terpenes, flavonoids and pathogenesis-related proteins (chitinase, $\beta$-1,3-glucanase, peroxidase, polyphenoloxidase), the lignification of cell walls, and callose synthesis (Reglinski et al. 2004, El Hadrami et al. 2010, Sharp 2013). Chitosan affects plant defences in two ways: it does not only activate genes responsible for the initiation of resistance mechanisms in plants, but also has properties proved to be antiviral (Pospieszny et al. 1991), antibacterial (Raafat \& Sahl 2009) and antifungal (Laflamme et al. 1999, Silva-Castro et al. 2018b). Moreover, it has been domonstrated that $\mathrm{CH}$ stimulates plant growth and development (Kumaraswamy et al. 2018). 
Salicylic acid (SA) is a phenolic compound that is a derivative of benzoic acid commonly found in plants at low concentrations (below $1 \mathrm{mg} \mathrm{kg}^{-1}$ fresh weight - Raskin et al. 1990). However, in infected plants its concentration can increase 20 -fold, activating the genes responsible for synthesizing defence-related proteins (Malamy et al. 1990). Both endogenous and exogenous SA induce local resistance, given its role of signal molecule for the development of systemic acquired resistance (Raskin 1992). Moreover, SA is an endogenous regulator of plant growth and development (Hayat et al. 2009, Rivas-San Vicente \& Plasencia 2011).

Oxalic acid (OA) is an organic acid widely distributed in plants, fungi and animals, and plays different roles in different living organisms (Wang et al. 2009). It is a virulence factor in several phytopathogenic fungi, including the model species Sclerotinia sclerotium (Marciano et al. 1983). In plants, it can play two distinct roles, depending on the concentration. While a high concentration of OA induces programmed cell death and contributes to the progression of fungi, a low concentration gives rise to plant resistance to fungi (Lehner et al. 2008).

Research on $\mathrm{CH}, \mathrm{SA}$ and $\mathrm{OA}$ as plant protection products and growth stimulants has so far concerned various herbaceous crop plants (Wang et al. 2009, El Hadrami et al. 2010, Rivas-San Vicente \& Plasencia 2011), while only few studies have focused on woody plants, including forest trees (Reglinski et al. 2004, Fitza et al. 2013, Aleksandrowicz-Trzcinska et al. 2015, Silva-Castro et al. 2018a). The aim of this work was thus to assess the effects of these three natural substances on the control of damping-off and growth among Scots pines at a bare-root nursery. Our null hypotheses were that: (1) all these substances limit seedling infection from damping-off; and (2) they have a favorable effect on pine growth.

\section{Materials and methods}

\section{Study site}

Field research was conducted in the bareroot forest nursery of Spychowo Forest District, located about $150 \mathrm{~km}$ north-east of Warsaw ( $53^{\circ} 36^{\prime} \mathrm{N}, 21^{\circ} 20^{\prime} \mathrm{E}$ - WGS 84), in Poland. The nursery was established on former agricultural land in 1976. The soil in the study area was classified as typical rusty. Earlier work on pine seedlings and the soil at this trial site revealed the presence of Rhizoctonia solani, Fusarium oxysporum and Alternaria sp. The annual mean temperature in the study area is $7.6^{\circ} \mathrm{C}$. The warmest month is July $\left(18.3{ }^{\circ} \mathrm{C}\right)$ and the coldest is January $\left(3.1^{\circ} \mathrm{C}\right)$. The vegetation period with an average daily temperature higher than $5^{\circ} \mathrm{C}$ is 207 days (Bureau for Forest Management and Geodesy 2013).

\section{Field experiment}

The experiment compared: pine seedlings treated with either $\mathrm{CH}(2 \%), \mathrm{SA}$ ( $1 \%$ and $2 \%$ ) or OA $(0.5 \%$ and $1 \%)$ and unprotected seedlings (control). The experiment was organised into a randomised-block design with four replicates. Within-block variants comprised 5 sown rows (seed tapes) over a length of $2 \mathrm{~m}$. The soil was prepared by full ploughing. A nursery marker adapted to five-row tapes was used to prepare furrows where the seeds were sown. Pine seeds of local origin from commercial stands were sown at $6.5 \mathrm{~g}$ of seed per metre of tape (i.e., 5 sown rows); this denotes 1250 seeds (about 250 seeds $/ 1$ m seedrow, 1250 seeds $\times 4$ blocks $=5000$ seeds per treatment). Seeds were covered by hand, under about $0.8 \mathrm{~cm}$ of soil. The experiment lasted 148 days, from June 6 to October 31.

\section{Applications of chitosan, salicylic acid} and oxalic acid

Chitosan was applied in the form of the commercial product called Beta-chikol ${ }^{\otimes}$ (Poli-Farm, Lowicz, Poland) as an organic plant-growth stimulant. Beta-chikol ${ }^{\circledast}(2 \%)$ was used according to manufacturer instructions. OA and SA were purchased from Biomus sp. z o.o. (Lublin, Poland), and were used as aqueous solutions.

All the substances were used in seed treatment. Seed were soaked in solutions for 6 hours (having not been prepared before treatment). Seeds from control variant were soaked in water. The substances were then further applied by foliar spraying 4 times during the growing season. The first application was made at the time of germination, and three subsequent ones at ten-day intervals. The concentrations were SA $1 \%$ and $2 \%$ OA $0.5 \%$ and $1 \%$, and Betachikol ${ }^{\circledR} 2 \%$.

\section{Seedling inventory and growth} measurement

Seedlings were inventoried three times during the growing season: 3 and 6 weeks after seed sowing, and at the season's end. All seedlings were counted in 1-metre segments of individual rows of the seedbed. There were 5 such segments in each treatment in a block. In late October, 40 seedlings in each treatment were collected and shoot and root length, root-collar diameter and dry mass of above-ground parts were measured.

\section{Statistical analyses}

A one-factor experiment was carried out for each type of tested substance. Addi-

Tab. 1 - Biometric parameters (with means and standard errors in parenthesis) for seedlings of Scots pine (Pinus sylvestris) protected with chitosan, salicylic acid and oxalic acid, and for those in the unprotected control. Means marked with different letters differ significantly ( $p<0.05$, Tukey HSD test). Results of ANOVAs ( $F$ and $p)$.

\begin{tabular}{|c|c|c|c|c|}
\hline $\begin{array}{l}\text { Treatment } \\
(\mathrm{n}=40)\end{array}$ & $\begin{array}{l}\text { Length of } \\
\text { shoot }(\mathrm{cm})\end{array}$ & $\begin{array}{c}\text { Dry mass of } \\
\text { above-ground parts (g) }\end{array}$ & $\begin{array}{c}\text { Root-collar } \\
\text { diameter }(\mathrm{mm})\end{array}$ & $\begin{array}{l}\text { Total root } \\
\text { length }(\mathrm{cm})\end{array}$ \\
\hline Chitosan & $6.1 \pm 0.119^{b}$ & $0.0925 \pm 0.0062^{b}$ & $0.85 \pm 0.0228^{b}$ & $12.5 \pm 0.404^{a}$ \\
\hline Control & $5.1 \pm 0.113^{a}$ & $0.0675 \pm 0.0050^{a}$ & $0.74 \pm 0.0215^{a}$ & $12.1 \pm 0.406^{a}$ \\
\hline$F$ & 33.17 & 9.58 & 14.29 & 0.54 \\
\hline$p$-value & $<0.0001$ & 0.0031 & 0.0004 & 0.2051 \\
\hline Oxalic acid $0.5 \%$ & $6.1 \pm 0.127^{b}$ & $0.0599 \pm 0.0027^{\mathrm{a}}$ & $0.83 \pm 0.0288^{b}$ & $13.2 \pm 0.278^{b}$ \\
\hline Oxalic acid 1\% & $6.2 \pm 0.128^{b}$ & $0.0711 \pm 0.0046^{a}$ & $0.79 \pm 0.0226 \mathrm{ab}$ & $12.0 \pm 0.321^{a}$ \\
\hline Control & $5.2 \pm 0.114^{a}$ & $0.0680 \pm 0.0051^{\mathrm{a}}$ & $0.73 \pm 0.0216^{a}$ & $12.0 \pm 0.400^{a}$ \\
\hline$F$ & 23.61 & 1.88 & 3.53 & 4.62 \\
\hline$p$-value & $<0.0001$ & 0.1593 & 0.0338 & 0.0125 \\
\hline Salicylic acid 1\% & $5.2 \pm 0.117^{b}$ & $0.0652 \pm 0.0043^{a}$ & $0.69 \pm 0.0170^{a}$ & $12.2 \pm 0.164^{a}$ \\
\hline Salicylic acid 2\% & $4.6 \pm 0.113^{a}$ & $0.0596 \pm 0.0033^{a}$ & $0.77 \pm 0.0105^{b}$ & $11.7 \pm 0.232^{a}$ \\
\hline Control & $5.1 \pm 0.114^{b}$ & $0.0674 \pm 0.0050^{a}$ & $0.72 \pm 0.0205^{a b}$ & $21.1 \pm 0.401^{a}$ \\
\hline$F$ & 9.05 & 1.00 & 6.74 & 1.02 \\
\hline$p$-value & 0.0003 & 0.3712 & 0.0019 & 0.3649 \\
\hline
\end{tabular}


tionally, for $\mathrm{CH}$ two-factor levels was used ( $\mathrm{CH}$ vs. control) whereas for OA and SA 3factor levels were used (OA: $0.5 \%, 1 \%$ and control; SA: $1 \%, 2 \%$ and control). We tested relationships among biometric parameters and numbers of seedlings germinating per 1-metre segment using a one-way Analysis of Variance (ANOVA) for complete randomised block design. The Tukey HSD test was used as post-hoc test in pairwise comparisons between different foliar sprays. Before analysis, the normality of the data distribution was verified using the ShapiroWilk test, while the equality of variances was assessed using the Levene test. All the studied factors presented a normal distribution and the variances were homogeneous. The statistical analysis was performed using $\mathrm{R}$ version 3.5.1.

\section{Results}

The growth of pine seedlings in the experiment was found to be stimulated by $\mathrm{CH}$. All biometric parameters except root length, were significantly higher than in the unprotected control. Oxalic acid at $1 \%$ concentration stimulated the growth of shoot length only. Better results were obtained where OA was present at $0.5 \%$, with stimulation of all growth parameters except dry mass of above-ground parts. Salicylic acid proved inhibitory to growth (only shoot length) where present at a $2 \%$ concentration, though no significant influence on biometric parameters was observed where the applied solution was $1 \%$ (Tab. 1).

Numbers of seedlings germinating per 1$\mathrm{m}$ segment of seed row after $\mathrm{CH}$ application were significantly greater than in the control variant (Fig. 1a). Likewise, OA applied at both concentrations was associated with higher numbers of germinating pine seedlings than in the control, albeit the statistical significance to these differences was achieved only 6 weeks after sowing the seeds, and only at a $0.5 \%$ concentration OA (Fig. 1b). Numbers of seedlings per metre-long segment were significantly lower in response to both concentrations of SA applied (Fig. 1C). Seedling emergence was affected most strongly by parasitic damping-off, as confirmed by specific symptoms (the narrowing into a root collar and blackening of stem bases causing seedling droop; and the blackening and death of roots) that were observed in all variants of the experiment.

\section{Discussion}

In some forest nurseries, the risk of parasitic damping-off (caused by different species of fungi or oomycetes) is high (Enebak et al. 1990, Beyer-Ericson et al. 1991), as confirmed by the results of our experiment, where major differences in the number of germinating pine seedlings among different experimental variants were observed. The main reason for the lack of seedling emergence or their death was damping-off, whose symptoms were clearly observed. The three substances applied
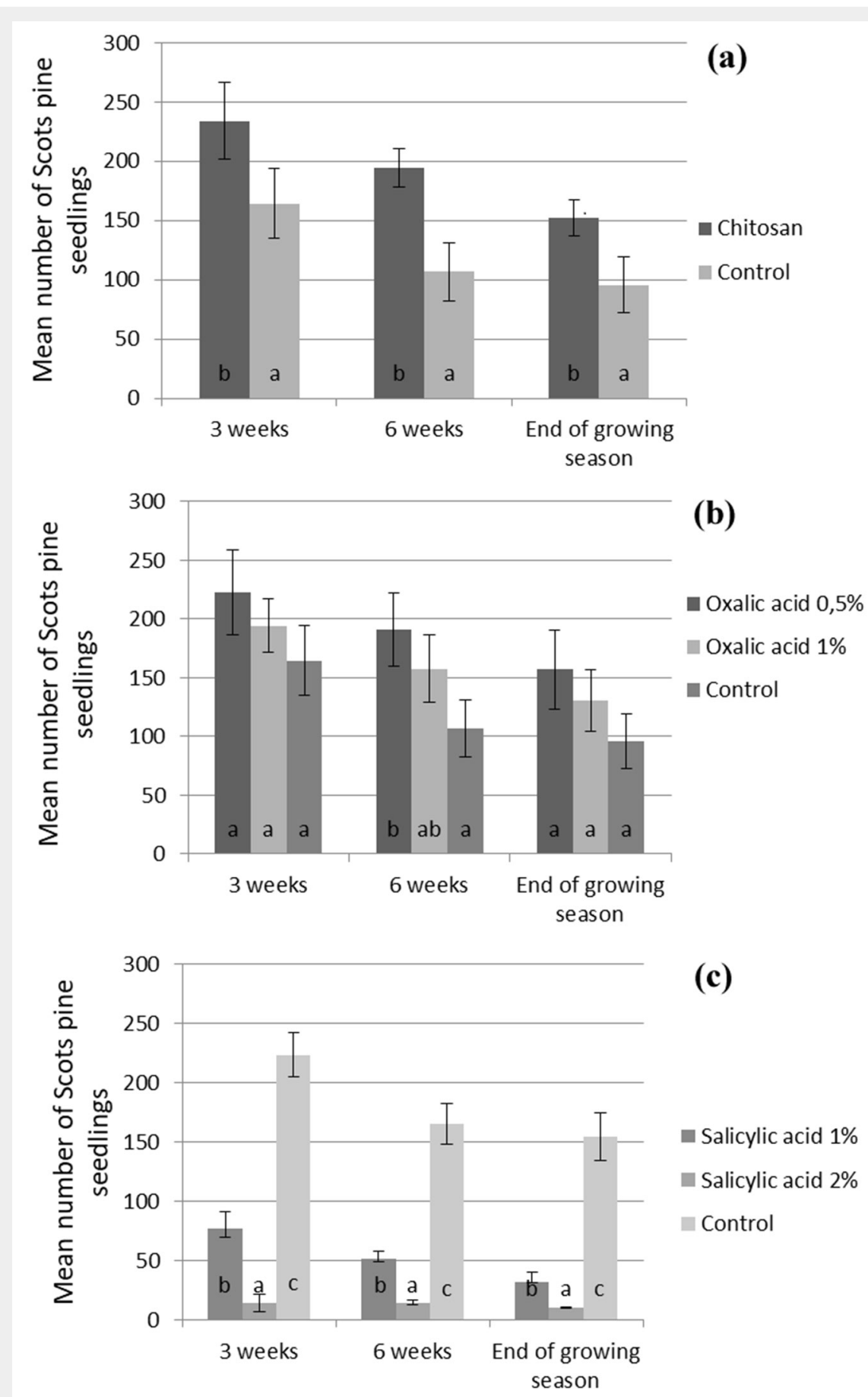

(c)

a Salicylic acid $1 \%$

- Salicylic acid $2 \%$

- Control

Fig. 1 - Mean numbers of Scots pine seedlings in 1-metre segments of the seed row 3 and 6 weeks after seed sowing and at the end of the growing season, in treatments with chitosan (A), oxalic acid (B), salicylic acid (C) or no protection (control). Means marked with different letters differ significantly $(p<0.05$, Tukey HSD test). Error bars denote standard errors.

in the experiment - $\mathrm{CH}, \mathrm{OA}$ and $\mathrm{SA}$ - are known for their capacity to induce plants' resistance reaction to unfavourable biotic and abiotic factors, as well as to stimulate growth (Malamy et al. 1990, Reglinski et al. 2004, Lehner et al. 2008). Nevertheless, as reported by many authors, the efficacy of these substances is dependent on various factors such as dose and concentration, the plant species involved and their stages of development, and the species of patho- gen involved (Duda et al. 2003, Rivas-San Vicente \& Plasencia 2011).

Our experiment revealed differentiated impacts of the analyzed substances on health state and growth of Scots pine seedlings. Both of our starting hypotheses were confirmed only in the case of $\mathrm{CH}$. The properties of $\mathrm{CH}$ as both a fungicide and growth stimulator have been rather wellstudied in many species, including woody plants (Reglinski et al. 2004, Fitza et al. 
2013, Aleksandrowicz-Trzcinska et al. 2015, Silva-Castro et al. 2018a). However, the results of such studies sometimes failed to offer unambiguous confirmation of the agent's effectiveness (Duda et al. 2003, Silva-Castro et al. 2018a). Unlike CH, SA and $\mathrm{OA}$ are not well known as plant protection agents, as well as in terms of their effectiveness and mode of action (Krokene et al. 2008, Jayaraj et al. 2010).

The result of our work offered undoubted confirmation of the effectiveness of the action of $\mathrm{CH}$ in protecting pine seedlings against damping-off, suggesting a multi-aspect pesticidal activity of $\mathrm{CH}$ (El Hadrami et al. 2010, Sharp 2013). The efficacy of CH in protecting seedlings may reflect a direct action of Beta-chikol ${ }^{\circledast}$ on fungi and oomycetes causing damping-off, due to its inhibitory effect against mycelial growth and the germination of spores (Laflamme et al. 1999, Silva-Castro et al. 2018b). A further mechanism may involve the capacity of chitosan molecules to bind the mycotoxins emitted by the facultative pathogens (i.e., the fungi causing damping-off), as these chemicals are known to be released to facilitate the colonisation of plant tissues (Bornet \& Teissedre 2008).

Chitosan applied in the form of Beta-chi$\mathrm{kol}^{\oplus}$ also determined a stimulated seedling growth. This applied to all of the parameters studied except root length. Similar effects have been observed in many other studies (Ohta et al. 2004, Cho et al. 2008, Aleksandrowicz-Trzcinska et al. 2015). However, the lack of impact on root growth was rather a surprise, given that $\mathrm{CH}$ can stimulate root-cell division by activating plant hormones such as auxin and cytokinin (Kumaraswamy et al. 2018).

A full identification of the mechanism underpinning plant growth stimulation due to $\mathrm{CH}$ treatment has not been achieved so far (Cho et al. 2008). The effect may involve a direct uptake of chitosan through roots, which could be utilized as an additional nutrient by plants (Ohta et al. 2004). Indeed, chitosan is a rich source of nitrogen, calcium and other microelements such as copper, zinc and iron (Bornet \& Teissedre 2008, Ramírez et al. 2010). Enhanced plant nutrition might also be due to the chelating properties of chitosan (Kumar 2000), which could favor a greater abundance of plant-growth promoting rhizobacteria and fungi, which in turn could favor plant growth (Ramamoorthy et al. 2001, Harman 2011).

Oxalic acid treatment showed a higher rate of seedling emergence and growth compared with untreated seedlings. However, better results were obtained with the lower concentration (0.5\%). The few studies on OA in the literature were focused on safeguarding rice against Rhizoctonia solani (Jayaraj et al. 2010), tomatoes against Fusarium oxysporum (Attitalla \& Brishammar 2002) and Norway spruce against bluestain fungus Ceratocystis polonica (Krokene et al. 2008). In our study, the effectiveness of $O A$ in protecting pine seedlings from damping-off was relatively limited and at a far lower level compared to $\mathrm{CH}$. However, a greater efficacy could be achieved at lower concentrations than those used in this study. Indeed, the levels of OA referred to as helpful in the literature vary greatly, from $3 \mathrm{mM}$ in the case of Arabidopsis thaliana against Sclerotium rolfsii, to 20 $\mathrm{mM}$ in the case of tomatoes and Fusarium oxysporum (Attitalla \& Brishammar 2002, Lehner et al. 2008).

Similar to SA, the protective effect to OA may depend both on the species to protect and the plant pathogen. The protective mechanisms are also very little-known, though (unlike $\mathrm{CH}$ and SA) OA has no antifungal properties (Attitalla \& Brishammar 2002). In contrast, Lehner et al. (2008) were able to demonstrate the induction of defence-related gene expression due to OA.

Thus far, research relating $O A$ and plant growth has been confined to herbaceous plants, pointing out the lack of any negative effects as a result of its application (Lehner et al. 2008). In contrast, a stimulation of seedling growth was observed in our study, especially at $0.5 \%$ OA concentration. Wang et al. (2009) showed that exogenous OA could delay fruit senescence by reducing ethylene production. Ethylene is known to serve as a plant hormone that inter alia produces inhibition of stem and root elongation (Ecker 1995). Based on our results, we may hypothesize that the inhibition of ethylene synthesis in cells following treatment with OA could lead to a stimulatory effect on seedling growth.

When SA was applied at either $1 \%$ or $2 \%$, it did not prove possible to sustain any of the research hypotheses put forward. Such treatments were associated with considerably smaller numbers of pine seedlings than in the control, suggesting either the lack of any protective effect of SA or even a toxic influence. This could be due to an excessive concentration of SA being applied in the experiment. However, as relevant research done hitherto was entirely confined to herbaceous plants, it is hard to suggest a concentration of exogenous SA that might be applied to ensure the effective safeguarding of woody plants against disease, and even the stimulation of their growth. This is all the more the case given that SA is known to have basal levels widely differing among species (up to 100-fold Raskin et al. 1990). What is more, disparities of this kind have been reported in species belonging to the same plant family ( Rivas-San Vicente \& Plasencia 2011).

The efficacy of SA in protecting seedlings from damping-off disease may depend on which species of fungal pathogen is causing the disease. Such a dependent relationship has been noted in the case of pathogens of genus Fusarium (Jankiewicz et al. 2013). Differential fungitoxicity due to SA may account for the limited effectiveness against damping-off, as this disease is caused by pathogens belonging to a wide range of systematic groups.

Several studies previously reported a delaying or inhibitory effect on seed germination due to SA (Rivas-San Vicente \& Plasencia 2011). This effect could explain the limited germination of pine seeds observed in this study, especially at higher concentrations.

The effect of exogenous SA on growth depends on the plant species, developmental stage and the SA concentrations tested (Rivas-San Vicente \& Plasencia 2011). Mechanisms by which SA influences plant growth have only been accounted for to a very limited degree so far. Shakirova et al. (2003) suggested that the growth-promoting effects of SA could be related to changes in hormonal status, while Stevens et al. (2006) invoked enhanced photosynthesis, transpiration and stomatal conductance. In this study, the lack of a stimulating effect seems to be related to the use of an excessive concentration of SA. High (1-5 $\mathrm{mM}$ ) SA concentration curbs photosynthetic rate and RuBisCO activity (Pancheva et al. 1996), as well as reduces chlorophyll content (Moharekar et al. 2003) and changes the leaf ultrastructure, particularly regarding chloroplasts (Uzunova \& Popova 2000). Similar (1-5 mM) concentration of SA is seen to inhibit respiration (Norman et al. 2004), while the concentrations applied in this study were still higher than those given above ( $1 \%$ and $2 \%$ ). Treatment of herbaceous plants with concentrations of SA below $1 \mathrm{mM}$ induced a growth stimulation (Rivas-San Vicente \& Plasencia 2011). Thus, the lack of the expected growth stimulation in pine seedlings observed in this work most probably reflects the high concentrations of SA applied, as well as the absence of any favourable influence of SA on photosynthesic process.

\section{Conclusion}

We tested the effect on Scots pine seedlings of three substances $(\mathrm{CH}$, applied as Beta-chikol ${ }^{\circledR}, \mathrm{OA}$, and SA), believed to have resistance-inducing and growth-stimulating properties in plants. The best result was obtained with $\mathrm{CH}$, which protected pine seedlings from damping-off and stimulated their growth. OA protected seedlings from damping-off to only a limited degree, though it was found to stimulate growth. However, better results were obtained when the lower concentration of OA (5\%) was applied. The application of SA did not result in seedlings protection from the fungal disease under consideration, nor did it significantly affect seedling growth. This most likely reflected the use of an excessive concentration of SA. In general, $\mathrm{CH}$ applied as Beta-chikol ${ }^{\circledR}$ may be recommended for use in forest nurseries as an alternative to fungicides in the protection of Scots pine seedlings from damping-off disease. In contrast, the effectiveness of SA and OA must be evaluated in further studies using lower concentrations of these substances. 


\section{Acknowledgments}

AS and GZ carried out the field experiment and lab measurements; MS performed the statistical analysis; MAT conceived the study and wrote the manuscript.

The authors extend their heartfelt thanks to Krzysztof Krasula, Forest Inspector of Spychowo Forest District, as well as to his deputy Maciej Ligocki for consenting to carry out the research work at the Piasutno Forest Nursery.

This work was supported by the Rector of Warsaw University of Life Sciences (SGGW) within the framework of research project no. 505-10-030400.

The editorial help of James R.A. Richards is also gratefully acknowledged.

\section{List of abbreviations}

$\mathrm{CH}$ : chitosan; OA: oxalic acid; SA: salicylic acid.

\section{References}

Aleksandrowicz-Trzcinska $M$, Bogusiewicz $A$ Szkop M, Drozdowski S (2015). Effect of chitosan on disease control and growth of Scots pine (Pinus sylvestris L.) in forest nursery. Forests 6 (9): 3165-3176. - doi: 10.3390/f6093165

Attitalla IH, Brishammar S (2002). Oxalic-acid elicited resistance to Fusarium wilt in Lycopersicon esculentum Mill. Plant Protection Science 38 (1): 128-131. - doi: 10.17221/10336-PPS

Beyer-Ericson I, Damm E, Unestam T (1991). An overview of root dieback and its causes in Swedish forest nursery. European Journal of Forest Pathology 21: 439-443. - doi: 10.1111/j.143 9-0329.1991.tboo781.x

Bornet A, Teissedre PL (2008). Chitosan, chitinglucan and chitin effects on minerals (iron, lead, cadmium) and organic (ochratoxin A) contaminants in wines. European Food Research and Technology 226: 681-689. - doi: 10.1007/s0o 217-007-0577-0

Bureau for Forest Management and Geodesy (2013). Management plan for Spychowo forest district for the years 2013-2022. Stand description data. Internal document for Spychowo Forest District, Bureau for Forest Management and Geodesy, Olsztyn, Poland.

Cho MH, No HK, Prinyawiwatkul W (2008). Chitosan treatments affect growth and selected quality of sunflower sprouts. Journal of Food Science 73 (1): 70-77. - doi: 10.1111/j.1750-3841.20 07.00607.x

Duda B, Oszako T, Piwnicki J (2003). Possibilities of chitosan use in forestry. Bulletin of the Polish Academy of Sciences, Biological Sciences 51: 213-220.

Ecker JR (1995). The ethylene signal transduction pathway in plants. Science 268: 667-675. doi: 10.1126/science. 7732375

El Hadrami A, Adam LR, El Hadrami I, Daayf F (2010). Chitosan in plant protection. Marine Drugs 8: 968-987. - doi: 10.3390/md8040968

Enebak SA, Palmer MA, Blanchette RA (1990). Managing soilborne pathogens of white pine in forest nursery. Plant Disease 74: 195-198. - doi: 10.1094/PD-74-0195

Fitza KNE, Payn KG, Steenkamp ET, Myburg AA, Naidoo S (2013). Chitosan application improves resistance to Fusarium circinatum in Pinus patula. South African Journal of Botany 85: 70-78. doi: 10.1016/j.sajb.2012.12.006

Goffeau A (2008). Drug resistance: the fight against fungi. Nature 452: 541-542. - doi: 10.103 8/452541a

Harman GE (2011). Multifunctional fungal plant symbionts: new tools to enhance plant growth and productivity. New Phytologist 189: 647649. - doi: 10.1111/j.1469-8137.2010.03614.X

Hayat Q, Hayat S, Irfan M, Ahmad A (2009). Effect of exogenous salicylic acid under changing environment: a review. Environmental and Experimental Botany 68 (1): 14-25. - doi: 10.1016/j. envexpbot.2009.08.005

Jankiewicz U, Golab D, Frak M (2013). Wplyw kwasu salicylowego syntetyzowanego przez bakterie Pseudomonas fluorescens i P. chlororapgis na fitopatogeniczne grzyby $z$ rodzaju Fusarium [The effect of salicylic acid, synthesized by the bacteria Pseudomonas fluorescens and $P$. chlororapgis on phytopathogenic fungi Fusarium]. Polish Journal of Agronomy 15: 6568. [in Polish]

Jayaraj J, Bhuvaneswari R, Rabindran R, Muthukrishnan S, Velazhahan R (2010). Oxalic acidinduced resistance to Rhizoctonia solani in rice is associated with induction of phenolics, peroxidase and pathogenesis-related proteins. Journal of Plant Interactions 5 (2): 147-157. - doi: 10.1080/17429140903291012

Krokene P, Nagy NE, Solheim H (2008). Methyl jasmonate and oxalic acid treatment of Norway spruce: anatomically based defense responses and increased resistance against fungal infection. Tree Physiology 28: 29-35. - doi: 10.1093/tre ephys/28.1.29

Kumaraswamy RV, Kumari S, Choudhary RC, Pal A, Raliya R, Biswas P, Saharan V (2018). Engineered chitosan based nanomaterials: bioactivities, mechanisms and perspectives in plant protection and growth. International Journal of Biological Macromolecules 113: 494-506. - doi: 10.1016/j.ijbiomac.2018.02.130

Kumar MNVR (2000). A review of chitin and chitosan applications. Reactive and Functional Polymers 46: 1-27. - doi: 10.1016/S1381-5148(00)0oo 38-9

Laflamme $P$, Benhamou N, Bussières G, Dessureault M (1999). Differential effects of chitosan on root rot fungal pathogens in forest nurseries. Canadian Journal of Botany 77: 14601468. - doi: 10.1139/b99-11

Lehner A, Meimoun P, Errakhi R, Madiona K, Barakate $M$, Bouteau $F$ (2008). Toxic and signaling effects of oxalic acid: natural born killer or natural born protector? Plant Signaling and Behavior 3: 746-748. - doi: 10.4161/psb.3.9.6634 Malamy J, Carr JP, Klessig DF, Raskin I (1990). Salicylic acid: a likely endogenous signal in the resistance response of tobacco to viral infection. Science 250: 1002-1004. - doi: 10.1126/scien ce.250.4983.1002

Marciano P, Dilenna P, Magro P (1983). Oxalic acid, cell wall degrading enzymes and $\mathrm{pH}$ in pathogenesis and their significance in the virulence of two Sclerotinia sclerotiorum isolates on sunflower. Physiological Plant Pathology 22: 339-345. - doi: 10.1016/S0048-4059(83)81021-2

Martín-García J, Zas R, Solla A, Woodward S, Hantula J, Vainio EJ, Mullett M, Morales-Rodrí- guez C, Vannini A, Martínez-Álvarez P, Pinto G, Alves A, Amaral J, Wingfield MJ, Fourie G, Steenkamp ET, Ahumada R, Šerá B, Sanz-Ros AV, Raposo R, Elvira-Recuenco M, Iturritxa E, Gordon TR, Diez JJ (2019). Environmentally friendly methods for controlling pine pitch canker. Plant Pathology 68: 843-860. - doi: 10.1111/ppa.13009

Moharekar ST, Lokhande SD, Hara T, Tanaka R, Tanaka A, Chavan PD (2003). Effects of salicylic acid on chlorophyll and carotenoid contents on wheat and moong seedlings. Photosynthetica 41: 315-317. - doi: 10.1023/b:phot.0000011970.62 172.15

Norman C, Howell KA, Millar H, Whelan JM, Day DA (2004). Salicylic acid is an uncoupler and inhibitor of mitochondrial electron transport. Plant Physiology 134: 492-501. - doi: 10.1104/pp. 103.031039

Ohta K, Morishita S, Suda K, Kobayashi N, Hosoki $\mathrm{T}$ (2004). Effects of chitosan soil mixture treatment in the seedling stage on the growth and flowering of several ornamental plants. Journal of the Japanese Society for Horticultural Science 73 (1): 66-68. - doi: 10.2503/jjshs.73.66

Pancheva TV, Popova LP, Uzunova AN (1996). Effects of salicylic acid on growth and photosynthesis in barley plants. Journal of Plant Physiology 149: 57-63. - doi: 10.1016/S0176-1617 (96)80173-8

Pospieszny H, Chirkov S, Atabekov J (1991). Induction of antiviral resistance in plants by chitosan. Plant Science 79: 63-68. - doi: 10.1016/016 8-9452(91)90070-O

Raafat D, Sahl H-G (2009). Chitosan and its antimicrobial potential - a critical literature survey. Microbial Biotechnology 2: 186-201. - doi: 10.1111/j.1751-7915.2008.00080.x

Ramamoorthy $V$, Viswanathan R, Raguchander T, Prakasam V, Samiyappan R (2001). Induction of systemic resistance by plant growth promoting rhizobacteria in crop plants against pests and diseases. Crop Protection 20: 1-11. - doi: 10.1016/S0261-2194(00)00056-9

Ramírez MA, Rodriguez AT, Alfonso L, Peniche C (2010). Chitin and its derivatives as biopolymers with potential agricultural applications. Biotecnologia Aplicada 27: 270-276.

Raskin I, Skubatz H, Tang W, Meeuse BJD (1990). Salicylic acid levels in thermogenic and nonthermogenic plants. Annals of Botany 66: 369373. - doi: 10.1093/oxfordjournals.aob.a088037 Raskin I (1992). Role of salicylic acid in plants. Annual Review of Plant Physiology and Plant Molecular Biology 43: 439-463. - doi: 10.1146/annu rev.pp.43.060192.002255

Reglinski T, Taylor JT, Dick MA (2004). Chitosan induces resistance to pitch canker in Pinus radiata. New Zealand Journal of Forestry Science 34: 49-58. [online] URL: http://www.scionre search.com/_data/assets/pdf_file/0003/59178/ 04_REGLINSKI.pdf

Rivas-San Vicente M, Plasencia J (2011). Salicylic acid beyond defence: its role in plant growth and development. Journal of Experimental Botany 62 (10): 3321-3338. - doi: 10.1093/jxb/err 031

Shakirova FM, Sakhabutdinova AR, Bezrukova $\mathrm{V}$, Fatkhutdinova RA, Fatkhutdinova DR (2003). Changes in the hormonal status of wheat seedlings induced by salicylic acid and 
salinity. Plant Science 164: 317-322. - doi: 10.10 16/S0168-9452(02)00415-6

Sharp RG (2013). A review of the applications of chitin and its derivatives in agriculture to modify plant-microbial interactions and improve crop yields. Agronomy 3: 757-793. - doi: 10.339 o/agronomy3040757

Silva-Castro I, Diez JJ, Martín-Ramos P, Pinto G, Alves A, Martín-Gil J, Martín-García J (2018a) Application of bioactive coatings based on chitosan and propolis for Pinus spp. protection against Fusarium circinatum. Forests 9: 685. - doi: $10.3390 / f 9110685$

Silva-Castro I, Martín-García J, Diez JJ, Flores-Pacheco JA, Martín-Gil J, Martín-Ramos P (2018b). Potential control of forest diseases by solutions of chitosan oligomers, propolis and nanosilver. European Journal of Plant Pathology 150: 40111. - doi: 10.1007/s10658-017-1288-4

Stevens J, Senaratna T, Sivasithamparam K (2006). Salicylic acid induces salinity tolerance in tomato (Lycopersicon esculentum cv. Roma): associated changes in gas exchange, water relations and membrane stabilisation. Plant
Growth Regulation 49: 77-83. - doi: 10.1007/s10 725-006-0019-1

Uzunova AN, Popova LP (2000). Effect of salicylic acid on leaf anatomy and chloroplast ultrastructure of barley plants. Photosynthetica 38: 243-250. - doi: 10.1023/A:1007226116925 Wang Q, Lai T, Qin G, Tian S (2009). Response of jujube fruits to exogenous oxalic acid treatment based on proteomic analysis. Plant Cell Physiology 50 (2): 230-242. - doi: 10.1093/pcp/pc n191 